\title{
New Trends: Time in Range and the Use of Continuous Glucose Monitoring Devices on Glycemic Control
}

\author{
Karyna Lucena Valença de Souza, Marcela Mascarenhas Braga Rassi, Diana Aristótelis Rocha de Sá, \\ Renata Maksoud Bussuan, Luciana Correa de Souza Rodrigues, and Alberto K. Arbex
}

\section{ABSTRACT}

Time in Range is a new concept in Diabetology, defining the percentage of the length of time in which the patient stays within a predetermined range of blood glucose. Electronic devices, from which the concept of Time in Range derived, help promote a better comprehension of these procedures, and may lead to a decrease in glycemic variability and to a lower risk of complications. It may also ease the control and adjustments in the treatment of diabetes. Therefore, the application of the Time in Range concept could generate a better diabetes control.

Diabetes Mellitus is a chronic metabolic disease caused by hyperglycemia due to changes related to insulin production and action. It has high morbidity and mortality and high prevalence and may affect several age groups. Currently, its classification is based on its etiology, with the most common diagnoses being pre-diabetes, type 1, type 2 and gestational diabetes. It should be investigated early in patients who have risk factors such as obesity and physical inactivity. It is diagnosed by alterations in fasting or random glucose measurement, oral glucose tolerance test and glycated hemoglobin. Its control and monitoring should be based on glycemic stability. Even more mechanisms are being developed to help the patient in the control of blood glucose, avoiding risks of acute and chronic complications, which can be severe and limiting.

Keywords: Diabetes Mellitus, Time in Range, vascular complications, glycemic variability, glycemic self-monitoring.
Submitted : September 16, 2020

Published : February 21, 2021

ISSN: $2593-8339$

DOI: $10.24018 /$ ejmed.2021.3.1.491

Karyna Lucena Valença de Souza IPEMED Medical School, São Paulo, Brazil.

Marcela Mascarenhas Braga Rassi IPEMED Medical School, São Paulo, Brazil.

Diana Aristótelis Rocha de Sá IPEMED Medical School, Brasília, Brazil.

Renata Maksoud Bussuan

IPEMED Medical School, Rio de Janeiro, Brazil.

Luciana Correa de Souza Rodrigues IPEMED Medical School, Brasília, Brazil.

Alberto K. Arbex*

IPEMED Medical School, São Paulo, Brazil.

Medical Clinic in Endocrinology and Diabetology, Schleswig-Holstein, Germany

(e-mail: albertoarbex ${ }^{@}$ gmail.com)

*Corresponding Author

\section{BACKGROUND}

Diabetes Mellitus (DM) is considered nowadays a serious public health issue, due to its high morbidity and mortality and the increasing number of people affected. The International Diabetes Federation (IDF) estimates that by 2040 there will be around 642 million individuals with DM ( 1 in 10 adults), including 23.2 million cases only in Brazil [1].

It is a chronic metabolic disease caused by elevated blood glucose, thus leading to what we call hyperglycemia. This elevation may be caused by changes or absence of insulin secretion as well as changes in its action. Insulin is a hormone produced by beta cells in the islets of Langerhans (pancreatic), whose main function is the uptake and transport of glucose to the interior of the cell so that it can undergo phosphorylation [2].

Since 1997 DM can be classified according to its etiology, and no longer by its treatment, into several types, the most common being DM1 (mediated by autoimmune or idiopathic process), DM2, gestational DM and also the rarer types such as MODY. (Maturity onset diabetes of the Young), endocrinopathies, drug-induced, associated with genetic diseases, among others [2].

DM2 is responsible for 90 to $95 \%$ of DM cases and its prevalence has varied in different nations, where its highest prevalence is still observed among the American Pima Indians, where $80 \%$ are obese and 55\% have DM2 [2].

DM1 is caused by a multifactorial autoimmune disorder, corresponding for 5 to $10 \%$ of all cases of DM, presenting in Brazil about 7.4/100,000 cases / year. It occurs predominantly in children and adolescents, most commonly between 15 and 20 years. It is considered the second most common chronic disease in childhood, with an increase in the last decades in children under 5 years [2], [3].

We also have an intermediate metabolic state between euglycemia and diabetes, called glucose intolerance. This concept was expanded and defined as impaired fasting glucose and impaired glucose tolerance in 1997 by the American Diabetes Association (ADA). It is of great importance to diagnose patients in this pre-diabetes (Pre-DM) metabolic state so can be proposed positive lifestyle changes, 
weight loss, and physical activity for at least 150 minutes per week, preventing disease progression and evolution to DM [2].

The diagnosis of Pre-DM and DM should be considered in the population with risk factors and in those who already have symptoms such as polyphagia, polypsy, polyuria and weight loss. They are performed through laboratory tests, such as fasting glucose, oral glucose tolerance test, glycated hemoglobin (A1C) and randomized glucose [3].

Long-term hyperglycemia or constant variations (peaks of hypoglycemia and hyperglycemia) in DM are associated with the development and progression of micro and macrovascular and non-vascular complications, making laboratory monitoring and self-monitoring of blood glucose essential, which should have its frequency adjusted individually.

Glucose self-monitoring is currently performed by glucometers, which measure capillary glucose by collecting blood drops at the fingertip. With the development of technology, continuous glucose monitoring through sensors that monitor interstitial glucose has also been used, providing greater monitoring of glycemic values throughout the day compared to intermittent capillary blood glucose.

With continuous glucose monitoring (CGMS) systems, it is possible to measure daily blood glucose variations due to numerous measurements, including nocturnal hypoglycemia and postprandial hyperglycemia, usually not evidenced by capillary blood glucose monitoring. Promoting decrease in cases of severe and asymptomatic hypoglycemia, constant hyperglycemia, effects of diet and physical activity on glycemic values and improvement of A1C values.

With continuous glucose monitoring (CGMS) systems, it is possible to measure daily blood glucose variations due to numerous measurements, including nocturnal hypoglycemia and postprandial hyperglycemia, usually not evidenced by capillary blood glucose monitoring. Promoting decrease in cases of severe and asymptomatic hypoglycemia, constant hyperglycemia, effects of diet and physical activity on glycemic values and improvement of A1C values.

In addition to technologies for monitoring blood glucose to maintain control close to physiological values, we also have Continuous Insulin Infusion Systems (CIS), known as "insulin pumps" which release pre-programmed amounts of insulin, trying to approximate maximum baseline values as well as ease of bolus administration. As a result, companies are investing in glucose check sensors that can communicate with CISs to facilitate DM control.

A new parameter was then created to assist in the control of DM known as Time in Range (TIR), discussed and set parameters at the Congress of Advanced Technologies \& Treatments for Diabetes (ATTD, February 2019), which comprises the determining a value range within which blood glucose should be maintained to prevent blood glucose swings and to better guide the patient in adjusting treatment based on factors affecting blood glucose.

\section{Methodology AND GoAls}

Time in Range has become a very relevant topic nowadays, where its goals are used to help on diabetes treatment control. It determines that the patient monitors the blood glucose values to make them more stable throughout the day, close to physiological, avoiding acute and chronic complications, due to the deleterious effects of glycemic variability. Its use is complementary to the use of glycated hemoglobin as a control of the effectiveness of the proposed therapeutic treatment. Allowing treatment adjustments at the time of acute glucose change.

Will this new parameter associated with technological advances, which facilitates the control of the patient with diabetes, effectively reduce the complications caused by uncontrolled blood glucose?

The present study had as source of study and references: scientific texts, books, magazines, journals, consensuses, notes and specialized websites, bringing current concepts, new technologies and expectations of improvements and goals in diabetes control.

Some of the various technological advances that help the goal of staying on target have been illustrated, with evidence of decreased glycemic oscillations providing a reduced risk of complications.

This study aims to evaluate the beneficial effects of maintaining glycemic values within a specific and predetermined target, minimizing glucose variations.

\section{A. General Goals}

Its main objective is to evidence the reduction of complications resulting from uncontrolled blood glucose, by orienting glucose value intervals, allowed throughout the day.

\section{B. Specific Goals}

Use of technological methods to maintain glycemic control and correct propedeutics, generating better diabetes control and reducing morbimortality.

Show a new look at diabetes control by complementing the actions already known for its monitoring avoiding glycemic variability.

\section{CURRENT Status OF GLyCEMIC CONTROL}

\section{A. Diabetes Mellitus}

"Diabetes is a complex, chronic illness requiring continuous medical care with multifactorial risk-reduction strategies beyond glycemic control" [4].

It is one of the most prevalent diseases today, encompassing a group of metabolic disorders associated with hyperglycemia, which due to its chronicity cause changes in lipid, carbohydrate and protein metabolism, altering the production and secretion of dysfunctional insulin [5], [6].

Among the main causes of the increase of diabetic cases in the world are the sedentary lifestyle, increasing cases of obesity, inadequate eating habits and longer life expectancy of the population. As a result, there was a significant increase in the number of absences from services, hospitalizations, dialysis treatments, sequelae that lead to disabilities for basic and instrumental daily life activities with deterioration in quality of life and early retirements [5], [6].

Smoking may increase the risk of type 2 diabetes7, so the incentive for stop smoking should be part of routine care for those with risk for diabetes. By the way, the years immediately following smoking cessation may represent a time of increased risk for diabetes [8]-[11].

These complications are caused by tissue and cellular 
damage due to oxidative stress and may affect both large and small vessels. Diabetes is known to be a major cause of nontraumatic lower limb amputations, dialytic chronic renal failure, and acquired blindness [3].

A lot of studies have attempted to analyze patients' perspectives on diabetes management, until yet few investigated foremost factors affecting their daily lives and their well-being [12]-[20].

TABLE I: PREVALENCE OF DM BY AGE IN BRAZIL

\begin{tabular}{cccc}
\hline \hline Age & Total $(\%)$ & Men $(\%)$ & Women $(\%)$ \\
\hline 18 - 24 years & 0,6 & 0,5 & 0,7 \\
25 - 34 years & 1,1 & 1,3 & 1 \\
35 - 44 years & 3,4 & 2,4 & 4,2 \\
45 - 54 years & 8,9 & 9,7 & 8,3 \\
55 - 64 years & 15,2 & 14,6 & 15,8 \\
$>$ 65 years & 21,6 & 23 & 20,7
\end{tabular}

Adapted Source: [5].

\section{1) Clinical condition}

Diabetes, in its vast majority of patients, is an asymptomatic disease, which explains why it is an oftenunderdiagnosed disease. In cases of patients with hyperglycemia and insulinopenics, most commonly in DM1 and DM2 without pancreatic reserve, the following classic symptoms can be found polyuria, polydipsia, polyphagia and weight loss. It may also be associated with weakness, fatigue, recurrent infections, fungal infections - especially in the genital regions, lethargy, among other nonclassical symptoms [3], [21].

\section{2) Tracking}

Identification of the patient at risk for diabetes is of extremely importance since with MEV measures and early treatment we can prevent the progression of a patient diagnosed with pre-DM for diabetes [21], [22].

The following patients should be screened for diabetes:

- $\quad$ Age $\geq 45$ years;

- Family history of diabetes, especially DM2;

- $\quad$ BMI $\geq 25 \mathrm{~kg} / \mathrm{m}^{2}$;

- Sedentary lifestyle;

- Low HDL $(\leq 40 \mathrm{mg} / \mathrm{dL}$ in men and $\leq 50 \mathrm{mg} / \mathrm{dL}$ in women) or high triglycerides;

- Arterial hypertension;

- Macrosomia or recurrent miscarriages or perinatal mortality;

- Gestational diabetes;

- Use of hyperglycemic drugs such as glucocorticoids, statins, thiazides, among others;

- Polycystic ovary syndrome (PCOS) due to insulin resistance;

- Presence of acute coronary disease.

\section{3) Laboratory diagnosis}

The request for laboratory tests for patient evaluation, according to the screening or suspicion of the disease, should be performed early. Fasting glucose, oral glucose tolerance test (TOTG), glycated hemoglobin (A1C) and randomized glucose are used for diagnosis [5], [6].

According to the ADA [22] and SBD [21], prediabetes patients are diagnosed with the following changes in the tests:

1. Fasting blood glucose between $100 \mathrm{mg} / \mathrm{dL}$ to
$125 \mathrm{mg} / \mathrm{dL}$, and / or

2. Blood glucose $2 \mathrm{~h}$ after $75 \mathrm{~g}$ glucose overload (during TOTG): with values ranging from $140 \mathrm{mg} / \mathrm{dL}$ to $199 \mathrm{mg} / \mathrm{dL}$, and / or

3. A1C between $5.7 \%$ and $6.4 \%$.

Below are the diagnostic criteria for diabetes, not used to differentiate its subtypes, which will be explained later [23].

TABLE II: DIAGNOSTIC CRITERIA FOR DIABETES.

A1C $\geq 6,5 \%=$ or $=$
fasting blood glucose $\geq 126 \mathrm{mg} / \mathrm{dL}=$ or $=$
glucose after OGTT $\geq 200 \mathrm{mg} / \mathrm{dL}=$ or $=$
any glucose $\geq 200 \mathrm{mg} / \mathrm{dL}$
Source adapted: SBD Official Positioning No 02/2018.
4) Treatment

Treatment for pre-diabetes and diabetes includes lifestyle changes plus associations, depending on the patient's clinical condition and weight, which include: antihyperglycemic agents on their own or combined therapies - whether oral or injectable, as well as use of Insulins [5], [6], [24], [25].

\section{5) Complications}

Glycemic monitoring is the target of diabetes treatment in order to avoid complications caused by blood glucose oscillations and constant hyperglycemia that cause endothelial dysfunction due to self-oxidation by free radical increases, which justify diabetes being a chronic inflammatory disease. This dysfunction may be present in the diagnosis of DM2 due to its frequent late diagnosis. In patients with DM1, they are usually present in the second decade of the diagnosis of diabetes, and investigations should be started from the fifth year of DM. The risk of developing these complications and endothelial changes is also associated with genetic predisposition [26]-[33].

Complications may be vascular and non-vascular. The microvascular ones are neuropathies, retinopathies, and nephropathies. The macrovascular complications are coronary artery disease, peripheral vascular disease, and cerebrovascular disease [26]-[33].

Peripheral diabetic neuropathy (PDN) has signs and / or symptoms of peripheral nerve dysfunction, affecting around $50 \%$ of DM2 patients and a smaller proportion of DM1 patients. It is characterized by symptoms of sensory predominance and limiting character, with stinging pain, burning, tingling, paresthesia, initially reaching distal to proximal region, which begins at rest and worsens at night [26], [29]-[31], [33]. It should be routinely and annually investigated at medical appointments, through physical examination and neurological tests, and encourage the patient to examine the feet daily for injuries and infections [3], [34][37]. Improved glycemic control has been shown to dramatically reduce the risk of DPN in people with type $1 \mathrm{DM}$ but only modestly reduce the incidence of DPN in type 2 DM [38]-[40].

Diabetic foot, defined by the World Health Organization (WHO) as "a condition of infection, ulceration or destruction of the deep tissues of the feet, associated with neurological abnormalities and varying degrees of peripheral vascular disease in the lower limbs of patients with diabetes mellitus." It has a prevalence in Brazil of $8 \%$ of the DM population, and $85 \%$ of lower limb amputations are preceded by ulcers. Thus, 
patients should also always be advised on footwear, moisturizing, nail trimming, hygiene, among others [2], [34][37].

Diabetic retinopathy is considered the most common chronic complication of diabetes, caused by the set of retinal and vitreous vascular changes that can lead to blindness. Semiannual or annual examinations with retinal mapping or angiography should be performed, in addition to visual acuity.

Diabetic nephropathy is one of the most serious complications and may be associated with obesity, hypertension and cardiovascular diseases, thus reducing life expectancy. It is considered to be the leading cause of dialytic chronic kidney disease in the United States. It should be monitored through tests such as serum creatinine associated with microalbuminuria dosage, an early marker of kidney disease, and may be isolated or 24-hour urine dosage [34][37].

Other complications include:

- Gastroparesis: due to lack of esophageal, gastric and intestinal motility, with difficulty in absorption, with clinical presentation of nausea, constipation or diarrhea.

- Sexual dysfunction: occurs in men with long diabetes, may have normal hormone levels, and can be treated with phosphodiasterase inhibitors.

- Skin changes: due to DM immunodepression.

Acute complications are considered endocrine emergencies caused by hyperglycemia, such as diabetic ketoacidosis and hyperglycemic hyperosmolar state. They are responsible for frequent hospitalizations of potentially fatal diabetes patients requiring intensive and complex treatment.

Another common acute complication is hypoglycemia, also considered fatal if there is no rapid treatment, which may appear in patients with intensive and rigid treatment. Patients may also have hypoglycemia during sleep, which may make it difficult to perform treatment for clinical improvement or to seek help. Some patients may also have neurological changes that affect the perception of signs / symptoms of hypoglycemia, known as: sweating, tachycardia, tremors, weakness, lethargy, mental confusion, seizure, coma, among others.

\section{B. Type 1 Diabetes Mellitus}

It is a chronic disease with absolute and definite insulin deficiency due to autoimmune or idiopathic causes. It can be diagnosed and differentiated from other types of diabetes by dosing the following autoantibodies: Anti-GAD (Glutamic Acid Antidecarboxylase), Pancreatic Anti-Islets (ICA), AntiInsulin (IAA), IA-2 and IA-2b.

(Anti-tyrosine phosphatase), and Anti ZnT8A, which precede hyperglycemia for months to years and may be only one or more present in the diagnosis.

The development of DM1 occurs in four phases:

- Preclinical: autoimmunity against beta cells;

- Clinical onset of DM;

- Transient remission: the so-called "honeymoon" phase;

- Established diabetes - acute and chronic complications may occur.

The treatment of DM1 is the use of insulin, and during the "honeymoon" period the patient may have a decreased need for daily amount as well as temporary withdrawal of medication. This period varies with each patient and can last around 2 years.

Insulin was isolated in 1921-22 at the University of Toronto by Frederick Banting, Charled Best, J.J.R. Macleod and James Collip, having in its structure 51 amino acids (aa), 2 peptide chains (A: 21aa and B: 30aa) linked by two disulfide bridges 16. Prior to its discovery, $100 \%$ of DM1 patients died early due to lack of proper treatment. Insulin has anabolic effect on muscle growth, glucagon storage and adipocyte augmentation. Some tissue effects are:

- Hepatic: inhibiting glycogenolysis and gluconeogenesis thus stimulating glycogen synthesis and glycolysis in order to save energy in the liver tissue.

- Adipose: inhibits lipase action avoiding lipolysis: lipogenesis.

- Muscle: Inhibits glycogenolysis by stimulating glycogen synthesis and glycolysis.

Insulins can be classified according to their pharmacokinetics into rapid acting, short acting, intermediate acting and long action, as shown below [41].

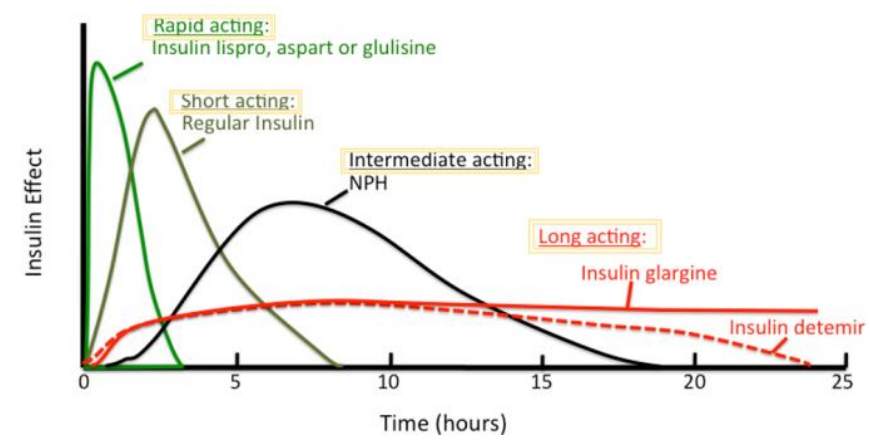

Fig. 1. Subtypes and approximate durations of action of different insulins. The duration of action of regular \& NPH insulin increases at higher doses. Adapted from [153].

They are administered subcutaneously and can be used by multiple daily injections, or they can also be used in continuous insulin infusion systems (CIS) for ultra-fast insulin [41].

Recently in Brazil, the National Health Surveillance Agency (Anvisa) approved the marketing of ultra-fast, inhalable insulin under the commercial name Afrezza ${ }^{\circledR}$ [42]. It is used by means of an inhaler, which is fitted with a cartridge for inhaling powder of the substance, still with a restricted dosage. Its use is contraindicated for patients with respiratory disorders such as Chronic Obstructive Pulmonary Disease, pulmonary fibrosis, and smokers.

Another way to use insulin is with the subcutaneous entry catheters or injection ports, such as i-Port Advance $\mathbb{R}$ (Medtronic MiniMed, Northridge, California) [43], [44]. They are devices inserted into the subcutaneous tissue for direct administration of medications, who can be applied in the same places on the body where insulin is applied directly by needles or pens: abdomen, back of the arm, hips and outer side of the thighs. I-Port Advance ${ }^{\circledR}$ can be kept in the skin for up to 3 days or 75 injections and used with long-acting or fast-acting insulins (being advised to apply the fast-acting insulin at least 1 hour before the slow one) [45]-[50]. 


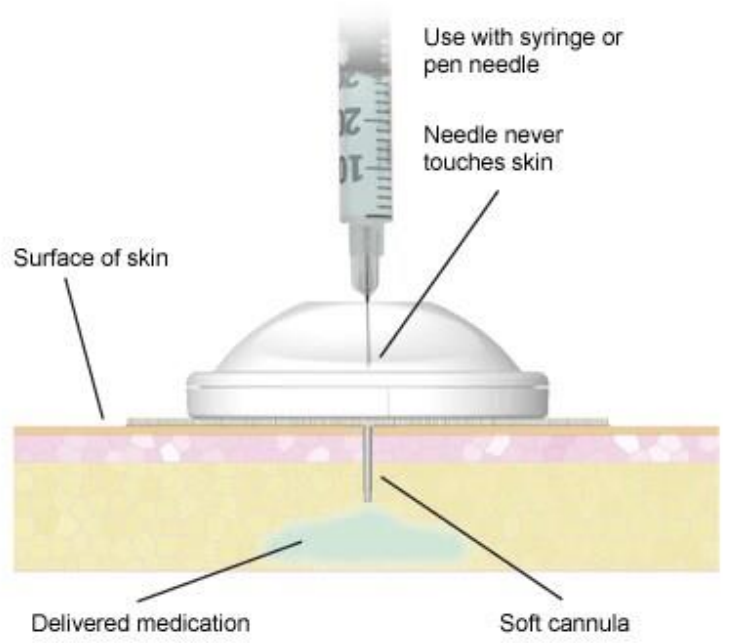

Fig. 2. i-Port Device.

Insert with an angle of $90^{\circ}$ and then removed, leaving only the flexible cannula under the skin [155].

\section{Diabetes Mellitus Type 2}

It is a complex, multifactorial, chronic disease that has a gradual evolution associated with a progressive beta cell insufficiency [51], [52].

About 30 to $50 \%$ of DM2 patients are asymptomatic or oligosymptomatic, compatible with the fact that the diagnosis in these patients is made late, about 4 to 7 years late. The diagnosis of T2DM usually appears after the age of 40, where most patients are obese who have associated liver and peripheral insulin resistance2,3,53. The pathophysiology of DM2 involves the so-called DeFronzo octet, which shows [51], [52]:

- Reduced incretinic effect: decreased insulin secretion and increased glucagon;

- Increased lipolysis: releasing fatty acid and leading to gluconeogenesis;

- Increased renal glucose resorption: excess of SGLT2;

- Peripheral uptake of reduced glucose;

- Neurotransmitter dysfunction, leading to increased appetite;

- Increased fasting and postprandial hepatic glucose production;

- Increased glucagon secretion by pancreatic islet alpha cells;

- Decreased Insulin secretion by pancreatic islet beta cells.

Regarding the treatment of DM2, we have as main and first indication the lifestyle change (SEM), which includes changes in diet and exercise, cessation of smoking and alcoholism if any. Subsequently and phase-dependent, oral medications should be initiated, initially in monotherapy and later, other oral antidiabetic agents or subcutaneous medications may be associated, such as GLP1 agonists and finally insulin, due to pancreatic failure [53]-[58].

The fact that DM2 is closely linked to cardiovascular risk factors, studies with antihyperglycemic medications are increasingly involved, in addition to glycemic control, in primary and secondary cardiovascular prevention. This has led to constant changes in treatment protocols and drug combinations, making therapies individualized for the patient
[53]-[57].

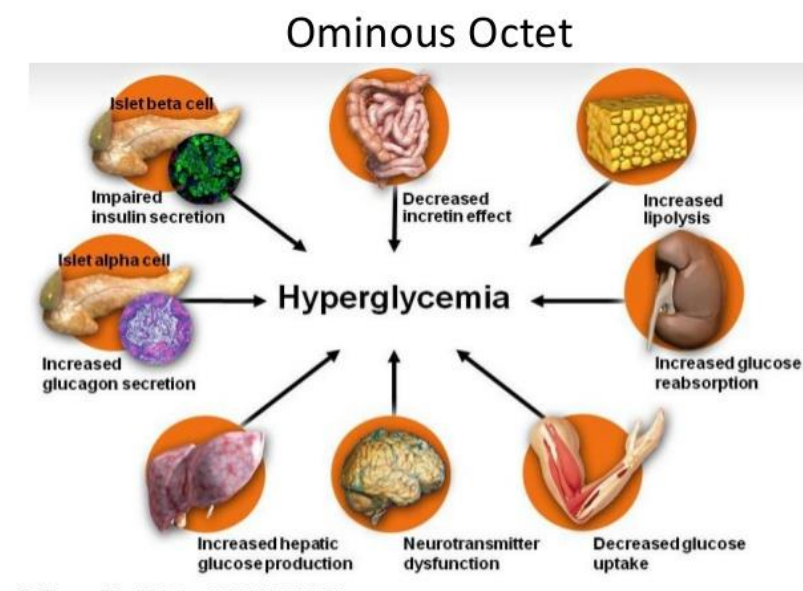

DeFronzo RA. Diabetes. 2009;58:773-795

Fig. 3. Pathogenesis of Type 2 diabetes mellitus ("nefarious octet") [156].

\section{Gestational Diabetes Mellitus}

It is considered when any degree of alteration in blood glucose occurs, identified for the first time during pregnancy, which may or may not persist after delivery. If this diagnosis is made at less than 20 weeks of gestational age or at the first prenatal visit, we consider pre-gestational DM [3].

It is responsible for complications for both mother, preeclampsia and evolution to cesarean delivery, as well as fetus, such as macrosomia, prematurity, neonatal hypoglycemia and perinatal death. DM should be investigated in all patients, being them with or without risk factors, with at least one fasting glucose dosage already at the first prenatal visit [58].

\section{E. Glycemic Monitoring and Time in Range}

Glycemic monitoring is performed to monitor the effectiveness of diabetes treatment. It is possible to evaluate blood glucose in real time through capillary blood glucose measurements or retrospective values, through laboratory blood glucose, A1C, fructosamine and continuous glycemic monitoring system. With these results it is possible to verify the actual follow-up of the patient and the need for modifications in the short or long term therapy [59]-[63].

Fasting or postprandial glycemia may be requested, but for DM1 patients it has little value for adjustment of therapeutic regimen, having better use in DM2 patients. A better representation of long-term control would be glycated hemoglobin (A1C), since it reflects the average glycemia during the last 2 to 3 months.

Another laboratory parameter to evaluate glycemic control is fructosamine, which reflects the last 10 to 14 days. Has restriction of interpretation in patients who have decreased serum proteins such as liver disease. Widely used in cases where therapeutic changes are required in a short time.

In addition to laboratory tests, it is possible to evaluate glycemic control at various times of the day, by means of capillary glucose measured by glucometer or interstitial glucose by continuous glucose monitoring system (CGMS). All of these parameters, associated with carbohydrate counting, are important for glycemic control and for maintaining the patient with more stable and close to normal values. 
TIR is a new concept that came to help control diabetes. It allows the avoidance of blood glucose oscillations that cannot be differentiated when measuring $\mathrm{A} 1 \mathrm{C}$, as it only represents an average [64]-[66]. Therefore, if the patient has several peaks of hyperglycemia as well as severe peaks of hypoglycemia over the same period, the average result may be considered a "normal" value by A1C measurement, but these oscillations generate as many risks of complications as continuous periods of hyperglycemia [64]-[66]. Below will be discussed elements that help the patient to remain on the safe target of blood glucose fluctuations [67]-[70].

Recent studies show that acute blood glucose fluctuations throughout the day also influence the onset of these complications. With this, studies that evaluate results of rigorous glycemic controls, capillary glycemia around 6 times a day in insulin-using patients, and continuous monitoring are increasing, in order to minimize the deleterious effects of glycemic control on the endothelium of patients with DM [67]-[70].

According to ADA71: "Studies have found that DSMES (Diabetes self-management education and support services) was associated with improved diabetes knowledge and selfcare behaviors [72], [73], lower A1C [72], [74]-[76], lower self-reported weight77,78, improved quality of life [75]-[79], reduced all-cause mortality risk [80], healthy coping [81], [82], and reduced health care costs [83], [84], [88]".

\section{1) $\mathrm{AlC}$}

Although glycated hemoglobin has been used since 1958 as a glycemic control assessment tool in patients with diabetes, A1C dosing has been increasingly employed and accepted by the scientific community after 1993, after being validated through both most important clinical studies on the impact of glycemic control on the chronic complications of diabetes: the DCCT Diabetes Control and Complications Trial [85]-[88] and the United Kingdom Prospective Diabetes Study [103].

One of the challenges of using $\mathrm{A} 1 \mathrm{C}$ as an indicator of glycemic control relates to individual differences in hemoglobin glycation. One study demonstrated a range of $\sim 80 \mathrm{mg} / \mathrm{dL}$ in average glucose for the same A1C level [89]. In 2008 another study showed that: "an A1C value of 7\% reflected average blood glucose ranging from 123 to 185 $\mathrm{mg} / \mathrm{dL}$; for an $\mathrm{A} 1 \mathrm{C}$ of $11 \%$, the range was even greater, at 217-314 mg/dL" [90]. A recent paper by Beck et al. [91] showed that: "varying patterns of glycemic control are possible even with identical A1C levels and similar mean glucose concentrations [52].

The National Glycohemoglobin Standardization Program (NGSP) aims to standardize A1C test results and relate to DCCT [85]-[88] and UKPDS [103], establishing direct relationships between $\mathrm{A} 1 \mathrm{C}$ levels and outcome risks in patients with DM.

Theoretical models and clinical studies suggest that a patient in stable control will have $50 \%$ of his A1C formed in the month preceding the exam, $25 \%$ in the month preceding the exam, and the remaining $25 \%$ in the third or fourth month before the exam [92].

According to SBD, A1C is used for diabetes diagnosis where we have the following reference values [93]:

- A1C below $5.7 \%=$ absence of diabetes;
- $\mathrm{A} 1 \mathrm{C}$ between $5.7 \%$ and $6.4 \%=$ presence of prediabetes;

- $\mathrm{A} 1 \mathrm{C}$ greater than or equal to $6.5 \%=$ diagnosis of diabetes.

The values for evaluation of glycemic control in people with diabetes are considered the following reference values:

- A1C between $4 \%$ to $6 \%=$ normal results;

- A1C between $6 \%$ to $7 \%=$ moderately controlled diabetes;

- A1C greater than 7\% = poorly controlled diabetes.

According to the UKPDS the average reduction of $1 \%$ in A1C results in a drop of $37 \%$ in microvascular complications, $14 \%$ of myocardial infarction and $21 \%$ of diabetes-related mortality.

The limitation of $\mathrm{A} 1 \mathrm{C}$ is the assessment of the magnitude and frequency of daily and long-term glucose variation, which may lead to an erroneous view of good glucose control, as seen in Fig. 6.

In addition, certain conditions such as anemia, hemoglobinopathies, and iron deficiency may confuse glycated hemoglobin measurements. Despite these limitations, it is the only tool that is prospectively used to assess the risk of diabetes complications, and its importance in clinical decision making should not be underestimated.

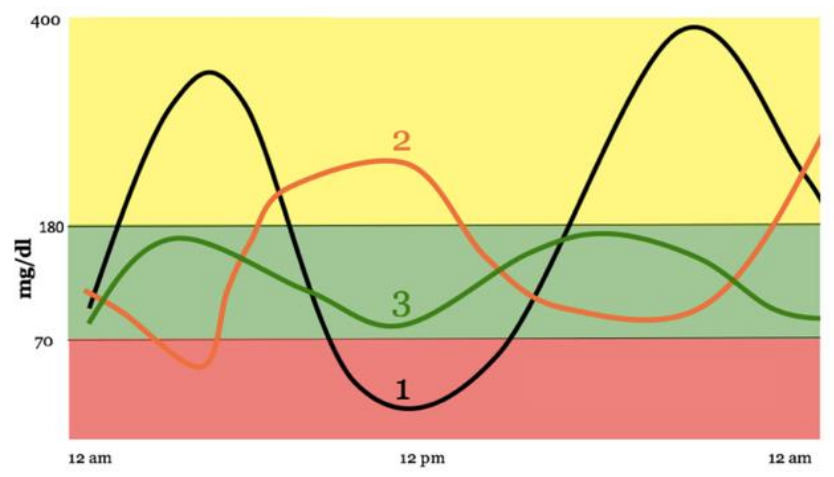

Time spent: High In range

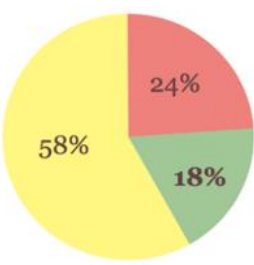

1

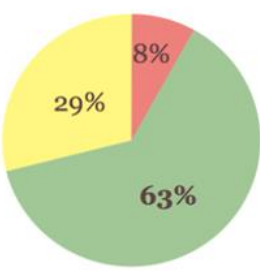

2

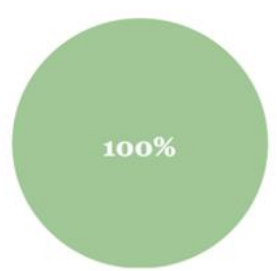

3
Fig. 4. The various expressions of 7\% A1C in 3 patients [157].

\section{2) Nutrition and carbohydrate counting}

Structured nutritional therapy for weight loss, with dietary changes, including a reduced calorie meal plan and physical activity, is of paramount importance for patients at high risk of developing type 2 diabetes associated with overweight or obesity [94]-[99].

Carbohydrate counting is a form of nutritional strategy to aid in glycemic control of the DM1 patient, where the carbohydrate grams consumed in meals are counted for better metabolic and glycemic control. With this it is possible to calculate, individually, the amount of insulin to be applied (bolus) for each amount of carbohydrate ingested, thus giving 
the patient greater freedom to eat various types of food and occasionally to consume even products containing sucrose. Lipid and protein calculations for insulin bolus administration are also being worked on [100].

\section{3) Continuous Subcutaneous Insulin Infusion - CSII}

Continuous Subcutaneous Insulin Infusion (CSII) "insulin pumps", allow you to release a scheduled and adjustable dose of basal insulin continuously over 24 hours, thus maintaining control of glucose levels between meals during at night and episodes that influence blood glucose [101].

They are devices that connect to the patient through a catheter and cannula in subcutaneous tissue, continuously releasing ultrafast insulin, with pre-calculated and adjustable basal administrations per hour and bolus. This form of treatment is the most similar to our physiological because it is possible to administrate small doses, according to the daily and hourly need.

They can be used by both adults and children, which improves treatment adherence, as the cannulas are changed every 3-4 days, significantly reducing the amount of daily "bites", allowing a better quality of life. The patient should also have a better control of blood glucose values either by capillary measurements or use of sensors to avoid hypoglycemia.

Some CSII already have the ability to connect to their own sensors, so that blood glucose values are sent and manually administered the insulin bolus. However, the automation of this process has not been approved yet. Unfortunately, these systems are still quite expensive, making it difficult for most patients to use.

- According to SBD indications for the use of CSII are [101]:

- Children under 7 years or with basal insulin dose $<10 \mathrm{U} / 24 \mathrm{~h}$;

- Uncontrolled dawn phenomenon to the use of fast and prolonged insulin analogues;

- Hypoglycemia <54mg / dL frequent;

- Hypoglycemia with severe cognitive impairment;

- Asymptomatic hypoglycemia.

\section{4) Glycemic Self-Monitoring}

The various glycemic checks throughout the day allow parameters such as diet, physical activity and stress to be assessed and may be adjusted by bolus in tables precalculated by professionals to obtain the glycemic goal. Fasting and pre-prandial blood glucose measurements are more often requested to assess the action of basal insulins; postprandial blood glucose measurements to evaluate the action of fast acting or ultrafast insulin. Measurement may also be requested at dawn, around 3 am to investigate nocturnal hypoglycemia or Somogyi effects, which generates peaks of fasting hyperglycemia due to hypoglycemia at dawn. The amount of glycemic tests, approximately 6 times a day, generates low adherence due to the high cost of blood glucose strips caused and finger pain due to digital puncture, thus leading to uncontrolled glycemic contro, A1C increases and risk of complications [102], [107]-[109].

\section{5) Continuous Glycemic Monitoring}

The CGM is a sensor that is implanted in subcutaneous tissue and transmits interstitial glucose values to a small monitor, with blood glucose averages sent every 5 minutes, where patients use the CGM for a minimum of 3 days, filling data with feeds and insulin data. They were widely used to verify glycemic control in patients with constant blood glucose oscillations [102], [107]-[109].

In recent years new sensors have been developed for personal use, also called "flash" CGM, which are also implanted in subcutaneous tissue, in the posterior face of the arms or abdominal region. When deployed and activated, they require $1 \mathrm{~h}$ to start measurements and last from 7 to 14 days, such as Freestyle libre ${ }^{\circledR}$ and Dexcom ${ }^{\circledR}$ (not yet available in Brazil) [102], [107]-[109].

The Freestyle ${ }^{\circledR}$ sensor checks glucose levels every minute and records an average value every 15 minutes, transmitting data for up to 8 hours to the receiver or smartphone. Data can be transmitted and generated reports that assist in treatment adjustments, allowing accurate data assessments, even when compared to capillary glycemia, unless they present high values of hyperglycemia and hypoglycemia. In such cases it is recommended to check also with capillary blood glucose to confirm the result [102], [107]-[109].

Early blood glucose sensors, even advanced in monitoring, were not able to issue alerts that inform patients of rapid changes, elevations, or drops in target glucose. Transmitters, such as the MiaoMiao, were then launched, which can be coupled to these sensors and, through Bluetooth connections, transmit to the applications installed on smartphones the glycemic values, giving different audible alerts for each programmed signaling [110], [111].

These transmitters have in their software customized adjustments of time parameters, A1C estimates, glycemic average, amount of hypoglycemic events and their minimum value, and can be generated reports for specific time periods, among other information [110], [111].

A closed-loop insulin delivery system (artificial pancreas) was showed to be more effective than sensor-augmented insulin pump therapy in patients with type 1 diabetes (T1D). [112] This system is not available in Brazil yet.

6) Trend Arrows

Trend arrows allow us to evaluate glucose behavior within minutes of measurement, thereby estimating significant episodes of hyperglycemia and hypoglycemia [101].

In analyzing CGM's decision-making trend arrows, we must evaluate several aspects [103]-[106]:

- Identify the current blood glucose.

- Evaluate the time of the last meal taken and the last bolus administration to estimate if you have active insulin.

- Investigate if you have been or will be affected by physical activity.

- Identify factors that cause glycemic loss such as recent stress, menstruation, sick days or use of hyperglycemic medications.

The results of the glycemic values sent from the sensor to the monitor generate a graph where it is possible to observe the tendency of elevation, fall or glycemia stability arrows, according to Table III. 
TABLE III: ARROWS OF GLUCOSE TREND AND RATE OF CHANGE PER MINUTE (MG / DL / MIN): [161]

\begin{tabular}{cccc}
\hline \hline Arrow & $\begin{array}{c}\text { Abbott Freestyle } \\
\text { Libre/Sensionics } \\
\text { Eversense }\end{array}$ & $\begin{array}{c}\text { Medtronic } \\
\text { Veo }\end{array}$ & $\begin{array}{c}\text { Medtronic } \\
640 \mathrm{G}\end{array}$ \\
\hline$\uparrow \uparrow \uparrow$ & NA & NA & $>3$ \\
$\uparrow \uparrow$ & NA & $>2$ & $2-3$ \\
$\uparrow$ & $>2$ & $1-2$ & $1-2$ \\
$\nearrow$ & $1-2$ & NA & NA \\
$\rightarrow$ & $<1$ & NA & NA \\
$\Downarrow$ & $1-2$ & NA & NA \\
$\downarrow$ & $>2$ & $1-2$ & $1-2$ \\
$\downarrow \downarrow$ & NA & $>2$ & $2-3$ \\
$\downarrow \downarrow \downarrow$ & NA & NA & $>3$ \\
\hline \hline NA: Not available. & & &
\end{tabular}

These trend arrows can be used to adjust bolus insulin treatment when using ultrafast insulin. There are several tables recently proposed by SBD 2019 positioning. These calculations should be discussed with the endocrinologist and their data carefully studied prior to these adjustments. Guidelines and protocols on SBD 2019 positions have recently been released.

\section{7) TIR - Time in Range}

An early study by DeWalt et al. [113] found that setting small and achievable goals not only improves people's ability to cope with diabetes, but also stimulates additional behavioral changes on their own.

The objective of time on target is to minimize glycemic variations and the risks of severe hyper or hypoglycemia, keeping the values close to the physiological, using the technological advances of patient monitoring and treatment [114]-[117].

TIR was associated with the presence of any stages for Cardiovascular autonomic neuropathy (CAN) independent of HbA1c metrics. TIR and other glycemic parameters assessed by CGM have high values and development potential as outcome measures [118]-[134].

Standardized values allow physicians to readily identify the target to be reached, as well as the percentage of time within, below and above each individual's target range, allowing for greater customization of therapy through shared decision making.

Several studies are being conducted showing the use of CGM with the elements mentioned above to evaluate A1C reduction and consequently the complications resulting from glycemic loss [135]-[139].

The ease of having a goal and staying on a specific target facilitates minimal oscillations within this range, allowing for greater adherence to glucose treatment and monitoring. These goals, being followed since the beginning of the diagnosis, gives the patient quality of life, less risk of developing vascular complications. And in patients who already have complications, it will help to prevent new complications or worsening of existing ones [140]-[144].

The Ambulatory Glucose Profile (AGP) report was adopted by most of the CGM device manufacturers in their software, so can help the patient to view his control of glucose
[140]-[143]. [145], [146].

8) AIC $x$ TIR

The ideal A1C target for adults with DM is approximately $7 \%$, and values between $7.5 \%$ and $8.5 \%$ may be acceptable depending on the patient's health status. 5 Recent parameters for glycemic control assessment include joint normalization of weekly blood glucose average $(150 \mathrm{mg} / \mathrm{dL}$, equivalent to A1C $=6.9 \%$ ), glycemic profile (normal plot within the acceptable range of glycemic values) and glycemic variability ( $<50 \mathrm{mg} / \mathrm{dL})$.

The use of GCM allows the direct assessment of glycemic oscillations and their daily profiles, identifying patterns of hypoglycemia and hyperglycemia, thus facilitating the patient to maintain an TIR of $70 \%$ [147], which would be compatible with an estimated 7\% of A1C.The DCCT showed that the better glycemic control and lower $\mathrm{A} 1 \mathrm{C}$ value, the lower the risk of complications in DM1 as shown below. Some patients even with acceptable A1C values for good control had complications, which can be explained by their result being an average of glycemic values, which will probably be explained and decreased with the use of TIR. TIR adds value as an outcome measure: it was shown to be strongly associated with clinical outcomes and risk of microvascular complications to diabetes. The hazard ratio (HR) of development of retinopathy was increased by $64 \%$ (95\% CI: 25-56) for each $10 \%$ lower TIR ( $\mathrm{p}<0,001)$. The HR of development of microalbuminuria was increased by $40 \%$ (95\% CI: 25-56) for each 10\% lower TIR (p<0,001) [148].

DCCT A1C - Levels and risk of complications in DM1

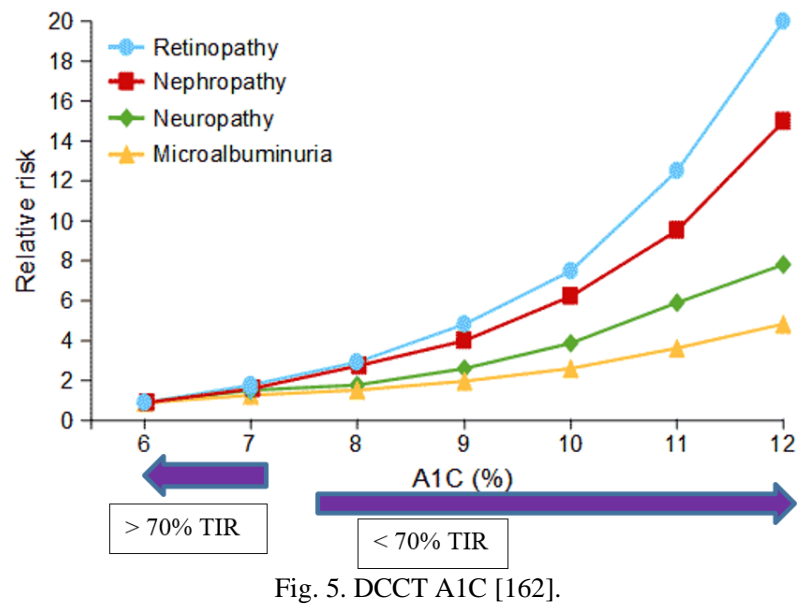

\section{9) TIR Goals}

The monthly issue of Diabetes Care, published in June 2019, by the American Diabetes Association, in an article by Battelino et al., Published the TIR Consensus recommendations regarding to glucose levels, which occurred preliminarily in Berlin at the Congress of Advanced Technologies in the Treatment of Diabetes [44]. 


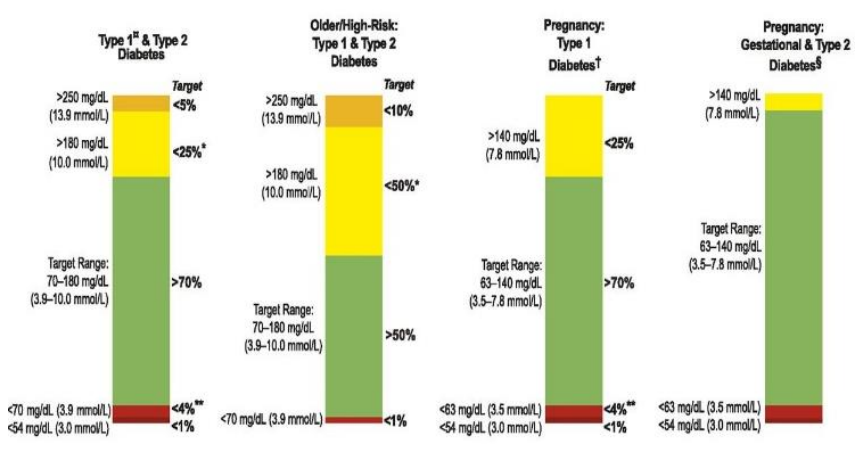

Fig. 6. Protocol of time in range [163].

In August 2019, SBD also enacted the target time consensus, where the following cutoff points were recommended 81, 149, 150, 23, 151, 152:

For most patients with DM1 and DM2:

- $>70 \%$ of time on target between 70-180 mg/dL (3.9$10.0 \mathrm{mmol} / \mathrm{L})$

- $\quad<4 \%$ of the time $<70 \mathrm{mg} / \mathrm{dL}(<3.9 \mathrm{mmol} / \mathrm{L})$;

- $<1 \%$ of time $<54 \mathrm{mg} / \mathrm{dL}(<3.0 \mathrm{mmol} / \mathrm{L})$;

- $<25 \%$ of the time $>180 \mathrm{mg} / \mathrm{dL}(>10.0 \mathrm{mmol} / \mathrm{L})$;

- $<5 \%$ of the time $>250 \mathrm{mg} / \mathrm{dL}$ ( $>13.9 \mathrm{mmol} / \mathrm{L}$ ).

For fragile patients at increased risk of hypoglycemia:

- $50 \%$ of time on target between 70-180 mg/dL (3.9$10.0 \mathrm{mmol} / \mathrm{L}$ );

- $\quad<1 \%$ of time $<70 \mathrm{mg} / \mathrm{dL}(<3.9 \mathrm{mmol} / \mathrm{L})$;

- $<10 \%$ of the time $>250 \mathrm{mg} / \mathrm{dL}(>13.9 \mathrm{mmol} / \mathrm{L})$.

For pregnant women:

- $>70 \%$ of time on target between $63-140 \mathrm{mg} / \mathrm{dL}$ (3.5$7.8 \mathrm{mmol} / \mathrm{L})$;

- $\quad<4 \%$ of the time $<63 \mathrm{mg} / \mathrm{dL}(<3.5 \mathrm{mmol} / \mathrm{L})$;

- $<1 \%$ of time between $<54 \mathrm{mg} / \mathrm{dL}(<3.0 \mathrm{mmol} / \mathrm{L})$;

- $<25 \%$ of the time above $>140 \mathrm{mg} / \mathrm{dL}(>7.8 \mathrm{mmol} / \mathrm{L})$.

\section{CONCLUSION}

Glycemic self-monitoring by GCM begins to spread in clinical practice. Its daily use gives an immediate feedback of current glucose levels, trends for rising or falling, and history of blood glucose levels. These information associated with the other elements already known for glycemic stabilization, enables that people with diabetes optimize exercise and diet, take informed decisions about therapy regarding meals and correction of insulin dosage, and, especially, react immediately and adequately to prevent acute glycemic events.

Automated insulin administration systems, insulin pump, combined with a continuous glucose sensor and an algorithm that determines insulin distribution, allow them to be able to suspend, increase or decrease insulin administration based on transmissions of blood glucose values by the sensor.

New systems are also being developed that, in addition to insulin administration and control, would have concomitant glucagon applications, thus simulating an artificial pancreas, further facilitating glycemic control, by goals set by the TIR.

In clinical practice, time in range (in, below or above target) is useful as clinical targets and outcome measures that complement A1C for a large group of diabetes patients.

In this sense, more complex and long-time studies related to the time within specific GCC glycemic ranges are needed, diabetes complications, and other outcomes in the various DM patient groups, to establish an effective and achievable goal for patients, and thus avoiding the acute and chronic complications of DM.

Several studies are still being conducted to further evaluate its effects and the benefits from its application.

\section{DECLARATION OF CONFORMITY TO ETHICAL STANDARDS}

The author states that this work is entirely original and is not submitted to any publisher. This is a study without conflicts of interest with institutions, colleagues or employees. No copyright was injured, and the graphics presented were produced by the author. Self-plagiarism does not apply to the work, and no experiments involving humans or animals were performed, as well as any questionnaire was applied. The research was carried out literally from relevant public references. No patients admitted to Brazilian hospitals were interviewed or asked to provide evidence related to hazardous materials risk. The author strongly condemns any predation on other works, always being alert to any possibility of textual misunderstandings that may give rise to doubts about copyright. No external financial support was raised for this work. The author supported the research with her own resources.

\section{FINANCING SOURCE}

There was neither a governmental nor an institutional financing source for this paper. The authors took all the costs involved on preparing this study.

\section{ACKNOWLEDGMENTS}

The authors would like to thank AFYA Educational for their continuous support of relevant studies in the field of Medicine and Endocrinology.

\section{CONTRIBUTION OF EACH AUTHOR}

KL, DARS and LCSR wrote the main paper; AKA, MM and $\mathrm{RMB}$ reviewed and expanded the final text.

\section{REFERENCES}

[1] Clinical Targets for Continuous Glucose Monitoring Data Interpretation: Recommendations from the International Consensus on Time in Range. Disponível em: https://care.diabetesjournals.org/content/42/8/1593 Acesso em Julho de 2019.

[2] American Diabetes Association. Standards of medical care in diabetes: 2012. Diabetes Care. 2012;35(Suppl 1):S11-63.

[3] Insulina Technosfere: Inhaled insulin for post prandial glucose control | Freddy Eliaschvitz. Disponível em: https://sbd.eadbox.com/courses/sitec-2019-simposio-internacional-detecnologias-em-diabetes Acesso em julho de 2019.

[4] Introduction: Standards of Medical Care in Diabetes-2020. Diabetes Care $2020 \quad$ Jan; 43(Supplement 1): S1-S2. https://doi.org/10.2337/dc20-Sint.

[5] Salles, P.; Halpern, A; Cercato, C. O Essencial em Endocrinologia 1a ed. 2016.

[6] Vilar, Lúcio. Endocrinologia Clínica - 6a edição, 2016. 
[7] Prevention or Delay of Type 2 Diabetes: Standards of Medical Care in Diabetes-2020 American Diabetes Association Diabetes Care 2020 Jan; 43(Supplement 1): S32-S36. https://doi.org/10.2337/dc20-S003.

[8] Yeh HC, Duncan BB, Schmidt MI, Wang NY, Brancati FL. Smoking, smoking cessation, and risk for type 2 diabetes mellitus: a cohort study. Ann Intern Med 2010;152:10-17.

[9] Oba S, Noda M, Waki K, et al.; Japan Public Health Center-based Prospective Study Group. Smoking cessation increases short-term risk of type 2 diabetes irrespective of weight gain: the Japan Public Health Center-based Prospective Study [published correction appears in PLoS One 2013;8:10.1371/annotation/23aa7c42-9a4d-42a7-8f509d0ac4b85396]. PLoS One 2012;7:e17061.

[10] $\mathrm{Hu}$ Y, Zong G, Liu G, et al. Smoking cessation, weight change, type 2 diabetes, and mortality. N Engl J Med 2018;379:623-632.

[11] Grock S, Ku J-H, Kim J, Moin T. A review of technology-assisted interventions for diabetes prevention. Curr Diab Rep 2017;17:107.

[12] Reaney M, Elash CA, Litcher-Kelly L. Patient reported outcomes (PROs) used in recent phase 3 trials for type 2 diabetes: a review of concepts assessed by these PROs and factors to consider when choosing a PRO for future trials. Diabetes Res Clin Pract 2016;116:54 67Google Scholar.

[13] Vieta A, Badia X, Sacristán JA. A systematic review of patientreported and economic outcomes: value to stakeholders in the decisionmaking process in patients with type 2 diabetes mellitus. Clin Ther 2011;33:1225-1245PubMedGoogle Scholar.

[14] Engström MS, Leksell J, Johansson U-B, Gudbjörnsdottir S. What is important for you? A qualitative interview study of living with diabetes and experiences of diabetes care to establish a basis for a tailored patient-reported outcome measure for the Swedish National Diabetes Register. BMJ Open 2016;6:e010249Abstract/FREE Full TextGoogle Scholar.

[15] Vanstone M, Rewegan A, Brundisini F, Dejean D, Giacomini M. Patient perspectives on quality of life with uncontrolled type 1 diabetes mellitus: a systematic review and qualitative meta-synthesis. Ont Health Technol Assess Ser 2015;15:1-29PubMedGoogle ScholarP. Reed Larsen \& Henry M. Kronenberg \& Shlomo Melmed \& Kenneth S. Polonsky Williams - Tratado de Endocrinologia Clínica - $11^{a}$ edição.

[16] Keely E, Traczyk L, Liddy C. Patients' perspectives on wait times and the referral-consultation process while attending a tertiary diabetes and endocrinology centre: is econsultation an acceptable option? Can J Diabetes 2015;39:325-329Google Scholar.

[17] Joensen LE, Filges T, Willaing I. Patient perspectives on peer support for adults with type 1 diabetes: a need for diabetes-specific social capital. Patient Prefer Adherence 2016;10:1443-1451Google Scholar.

[18] Polonsky WH, Fisher L, Hessler D, Bruhn D, Best JH. Patient perspectives on once-weekly medications for diabetes. Diabetes Obes Metab 2011;13:144-149CrossRefPubMedGoogle Scholar.

[19] Sullivan-Bolyai S, Bova C, Johnson K, et al. Engaging teens and parents in collaborative practice. Diabetes Educ 2014;40:178190CrossRefPubMedGoogle Scholar.

[20] Nadal JF, Barba EL, Garcia CG, Buil-Cosiales P, Millaruelo JM, Peña MLO. Patient-reported outcomes in type 2 diabetes mellitus: patients' and primary care physicians' perspectives in the Spanish health care system. Patient Prefer Adherence 2015;8:1413-1422.

[21] Sociedade Brasileira de Diabetes. Diretrizes da Sociedade Brasileira de Diabetes 2017-2018. São Paulo: AC Farmacêutica; 2019. Disponível em:

http://formsus.datasus.gov.br/novoimgarq/41252/8137296_312361.pd f Acesso em 20 de agosto de 2019.

[22] American Diabetes Association. 2. Classification and Diagnosis of Diabetes. Diabetes Care. 2018;41(Suppl 1):S13-S27.

[23] Posicionamento Oficial SBD, SBPC-ML, SBEM e FENAD 2017/2018. Atualização Sobre Hemoglobina Glicada (A1c) Para Avaliação Do Controle Glicêmico E Para O Diagnóstico Do Diabetes: Aspectos Clínicos E Laboratoriais Disponível em: https://www.diabetes.org.br/publico/images/banners/posicionamento3-2.pdf Acesso em agosto de 2019.

[24] Guo XH (2016): The value of short- and long-acting glucagon-like peptide- 1 agonists in the management of type 2 diabetes mellitus: experience with exenatide. Curr Med Res Opin. 32(1):61-76. doi: 10.1185/03007995.2015.1103214.

[25] Dungan K (2019): Amylin analogs for the treatment of diabetes mellitus. In: UpToDate, Basow, DS (Ed), Waltham, MA. Cited $11 / 12 / 19$.

[26] The ACCORD Study Group. Nine-year effects of 3.7 years of intensive glycemic control on cardiovascular outcomes. Diabetes Care 2016;39:701-8

[27] Progression of retinopathy with intensive versus conventional treatment in the Diabetes Control and Complications Trial Re- search Group. Ophthalmology. 1995;102(4):647-61.
[28] The relationship of glycemic exposure (HbA1c) to the risk of development and progression of retinopathy in the Diabetes Control and Complications Trial. Diabetes. 1995;44(8):968-83.

[29] Rosenberg JB, Tsui I. Screening for diabetic retinopathy. N Engl J Med. 2017;376(16):1587-8.

[30] ADA (2017): American Diabetes Association Standards of Medical Care in Diabetes - 2017. Diabetes Care. 40 (Suppl 1): S1-138.

[31] Li R, Zhang P, Barker LE, Chowdhury FM, Zhang X. Costeffectiveness of interventions to prevent and control diabetes mellitus: a systematic review. Diabetes Care 2010;33:1872-1894.

[32] Cox DJ, Gonder,Frederick L, Polonsky W, Schlundt D, Kovatchev B, Clarke W. Blood glucose awareness training (BGAT-2): long-term benefits. Diabetes Care 2001;24:637-642.

[33] Riddlesworth TD, Beck RW, Gal RL, et al. Optimal sampling duration for continuous glucose monitoring to determine long-term glycemic control. Diabetes Technol Ther2018;20:314-316pmid:29565197.

[34] Vincent AM, Russell JW, Low P, et al. Oxidative stress in the pathogenesis of diabetic neuropathy. Endocr Rev2004;25:612 28.doi:10.1210/er.2003-0019.

[35] Pop-Busui R, Sima A, Stevens M. Diabetic neuropathy and oxidative stress. Diabetes Metab Res Rev2006;22:25773.doi:10.1002/dmrr.625.

[36] de Boer IH, Group DER, DCCT/EDIC Research Group. Kidney disease and related findings in the diabetes control and complications trial/epidemiology of diabetes interventions and complications study. Diabetes Care2014;37:24-30.doi:10.2337/dc13-2113.

[37] Nathan DM, Genuth S, Lachin J, et al. The effect of intensive treatment of diabetes on the development and progression of long-term complications in insulin-dependent diabetes mellitus. $\mathrm{N}$ Engl J Med1993;329:977-86.doi:10.1056/NEJM199309303291401.

[38] The effect of intensive diabetes therapy on the development and progression of neuropathy. The diabetes control and complications trial Research Group. Ann Intern Med1995;122:561-8.doi:10.7326/00034819-122-8-199504150-00001.

[39] Pop-Busui R, Lu J, Lopes N, et al. Prevalence of diabetic peripheral neuropathy and relation to glycemic control therapies at baseline in the Bari 2D cohort. J Peripher Nerv Syst2009;14:1-13.

[40] Ismail-Beigi F, Craven T, Banerji MA, et al. Effect of intensive treatment of hyperglycaemia on microvascular outcomes in type 2 diabetes: an analysis of the ACCORD randomised trial. Lancet2010;376:419-30.doi:10.1016/S0140-6736(10)60576-4

[41] McCulloch DK (2016): General principles of insulin therapy in diabetes mellitus. In: UpToDate, Basow, DS (Ed), Waltham, MA Cited 2/7/17.

[42] https://www.diabetes.org.br/publico/noticias-sbd/1853-anvisa-aprovainsulina-inalavel - Acesso em 20 de Agosto de 2019.

[43] Hanas R, de Beaufort C, Hoey H, Anderson B. Insulin delivery by injection in children and adolescents with diabetes. Pediatric Diabetes. 2011;12(5):518-26.

[44] Medtronic. i-Port AdvanceTM injection port. [Internet]. [acesso em fevereiro de 2020]. Disponível em: https://www.medtronicdiabetes.com/products/i-port-advance.

[45] Diretrizes da Sociedade Brasileira de Diabetes 2019-2020 Acessado em fevereiro de 2020, disponível em: https://www.diabetes.org.br/profissionais/images/DIRETRIZESCOMPLETA-2019-2020.pdf.

[46] Riley D, Raup GH. Impact of a subcutaneous injection device on improving patient care. Nurs Manage. 2010;41(6):49-50.

[47] Khan AM, Alswat KA. Benefits of Using the i-Port System on InsulinTreated Patients. Diabetes Spectr. 2019;32(1):30-35.

[48] Goldberg T, Wong E. Afrezza (Insulin Human) Inhalation Powder: A New Inhaled Insulin for the Management of Type-1 or Type-2 Diabetes Mellitus. P T. 2015;40(11):735-41.

[49] Mohanty RR, Das S. Inhaled Insulin - Current Direction of In- sulin Research. J Clin Diagn Res. 2017;11(4):OE01-OE02.

[50] Danne T, Nimri R, Battelino T, Bergenstal RM, Close KL, De-Vries $\mathrm{JH}$, et al. International Consensus on Use of Continuous Glucose Monitoring. Diabetes Care. 2017;40(12):1631-40.

[51] Novas Abordagens Intensivas Para O Controle Do Diabetes Tipo 2. Disponível https://www.diabetes.org.br/profissionais/images/pdf/apresentacoesmedicas/novas-abordagens.pdf Acessado em 01 de agosto de 2019.

[52] Posicionamento Oficial SBD no 01/2019 Conduta Terapêutica No Diabetes Tipo 2: Algoritmo SBD 2019. Disponível em: https://www.diabetes.org.br/publico/images/pdf/sbd_dm2_2019_2.pdf Acesso em Agosto de 2019.

[53] Controvérsia E Avanços Tecnológicos Sobre Hemoglobina Glicada (A1C). Disponível em: https://www.diabetes.org.br/profissionais/images/pdf/apresentacoesmedicas/ahemoglobina-glicada.pdf Acesso em 23 de agosto de 2019. 
[54] ASSOCIAÇ̃̃O Brasileira para o Estudo da Obesidade e da Síndrome Metabólica. Diretrizes brasileiras de obesidade 2016 / ABESO Associação Brasileira para o Estudo da Obesidade e da Síndrome Metabólica. 4. ed. São Paulo, SP.

[55] FALUDI, A. A. et al. Atualização da Diretriz Brasileira de Dislipidemias e Prevenção da Aterosclerose. PubMed. 2017.

[56] Intensive Glucose Control in Patients with Type 2 Diabetes - 15-Year Follow-up Disponível em https://www.nejm.org/doi/full/10.1056/NEJMoa1806802. Acesso em julho de 2019.

[57] Buse JB et al (2019): 2019 Update to: Management of Hyperglycemia in Type 2 Diabetes, 2018. A Consensus Report by the American Diabetes Association (ADA) and the European Association for the Study of Diabetes (EASD). Diabetes Care. https://doi.org/10.2337/dci19-0066.

[58] P. Reed Larsen \& Henry M. Kronenberg \& Shlomo Melmed \& Kenneth S. Polonsky Williams - Tratado de Endocrinologia Clínica $11^{\mathrm{a}}$ edição.

[59] Haak T, Hanaire H, Ajjan R, Hermanns N, Riveline JP, Rayman G. Flash glucose-sensing technology as a replacement for blood glucose monitoring for the management of insulin-treated type 2 diabetes: a multicenter, open-label ran- domized controlled trial. Diabetes Ther 2017;8: 55-73.

[60] Burant CF, Young LA American Diabetes Association. Medical Management of Type 2 Diabetes. 7th ed. Burant CF, Young LA, Eds. Alexandria, VA, American Diabetes Association, 2012.

[61] Grant RW, Kirkman MS. Trends in the evidence level for the American Diabetes Association's "Standards of Medical Care in Diabetes" from 2005 to 2014. Diabetes Care 2015;38:6-8.

[62] Mazze RS, Lucido D, Langer O, Hartmann K, Rodbard D. Ambulatory glucose profile: representation of verified self-monitored blood glucose data. Diabetes Care 1987;10:111-117pmid:3552508.

[63] Fonseca V, Grunberger G. Letter to the editor: standard glucose reporting: follow-up to the February 2016 AACE CGM Consensus Conference. Endocr Pract 2017;23:629-632pmid:28467179.

[64] Self-monitoring of blood glucose in non-insulin treated type 2 diabetes Innternacional Diabetes Federation - Disponível em https://www.idf.org/e-library/guidelines/85-self-monitoring-of-bloodglucose-in-non-insulin-treated-type-2-diabetes.html Acesso em 13 de agosto de 2019.

[65] Pickup JC, Freeman SC, Sutton AJ. Glycaemic control in type 1 diabetes during real time continuous glucose monitoring compared with self monitoring of blood glucose: meta-analysis of randomised controlled trials using individual patient data. BMJ 2011; 343:d3805.

[66] Time in Range: the new metric for Diabetes | Robert Vigerski Disponível em: https://sbd.eadbox.com/courses/sitec-2019-simposiointernacional-de-tecnologias-em-diabetes Acesso em julho de 2019.

[67] Wang CC, Shah AC. American Diabetes Association. Medical Management of Type 1 Diabetes. 7th ed. Wang CC, Shah AC, Eds. Alexandria, VA, American Diabetes Association, 2017.

[68] Gonder-Frederick LA, Schmidt KM, Vajda KA, et al Psychometric properties of the Hypoglycemia Fear Survey-II for adults with type 1 diabetes. Diabetes Care 2011;34:801-806

[69] Cox DJ, Kovatchev B, Koev D, et al. Hypoglycemia anticipation, awareness and treatment training (HAATT) reduces occurrence of severe hypoglycemia among adults with type 1 diabetes mellitus. Int J Behav Med 2004.

[70] Kilpatrick ES, Rigby AS, Goode K, Atkin SL. Relating mean blood glucose and glucose variability to the risk of multiple episodes of hypoglycaemia in type 1 diabetes. Diabetologia2007;50:25532561 pmid: 17882397.

[71] Facilitating Behavior Change and Well-being to Improve Health Outcomes: Standards of Medical Care in Diabetes-2020 American Diabetes Association. Diabetes Care 2020 Jan; 43(Supplement 1): S48 S65. https://doi.org/10.2337/dc20-S005.

[72] Norris SL, Lau J, Smith SJ, Schmid CH, Engelgau MM. Selfmanagement education for adults with type 2 diabetes: a meta-analysis of the effect on glycemic control. Diabetes Care 2002;25:1159-1171.

[73] Haas L, Maryniuk M, Beck J, et al.; 2012 Standards Revision Task Force. National Standards for Diabetes Self-Management Education and Support. Diabetes Care 2013;37(Suppl. 1):S144-S153.

[74] Frosch DL, Uy V, Ochoa S, Mangione CM. Evaluation of a behavior support intervention for patients with poorly controlled diabetes. Arch Intern Med 2011;171:2011-2017.

[75] Cooke D, Bond R, Lawton J, et al.; U.K. NIHR DAFNE Study Group. Structured type 1 diabetes education delivered within routine care: impact on glycemic control and diabetes-specific quality of life. Diabetes Care 2013;36:270-272.
[76] Chrvala CA, Sherr D, Lipman RD. Diabetes self-management education for adults with type 2 diabetes mellitus: a systematic review of the effect on glycemic control. Patient Educ Couns2016;99:926-943

[77] Steinsbekk A, Rygg LØ, Lisulo M, Rise MB, Fretheim A. Group based diabetes self-management education compared to routine treatment for people with type 2 diabetes mellitus. A systematic review with metaanalysis. BMC Health Serv Res 2012;12:213.

[78] Deakin T, McShane CE, Cade JE, Williams RDRR. Group based training for self-management strategies in people with type 2 diabetes mellitus. Cochrane Database Syst Rev 2005;2:CD003417.

[79] Cochran J, Conn VS. Meta-analysis of quality of life outcomes following diabetes self-management training. Diabetes Educ 2008;34:815-823.

[80] He X, Li J, Wang B, et al. Diabetes self-management education reduces risk of all-cause mortality in type 2 diabetes patients: a systematic review and meta-analysis. Endocrine 2017;55:712-731.

[81] Thorpe CT, Fahey LE, Johnson H, Deshpande M, Thorpe JM, Fisher EB. Facilitating healthy coping in patients with diabetes: a systematic review. Diabetes Educ 2013;39:33-52.

[82] Fisher L, Hessler D, Glasgow RE, et al. REDEEM: a pragmatic trial to reduce diabetes distress. Diabetes Care 2013;36:2551-2558.

[83] Robbins JM, Thatcher GE, Webb DA, Valdmanis VG. Nutritionist visits, diabetes classes, and hospitalization rates and charges: the Urban Diabetes Study. Diabetes Care 2008;31:655-660.

[84] Duncan I, Ahmed T, Li QE, et al. Assessing the value of the diabetes educator. Diabetes Educ2011;37:638-657.

[85] Diabetes Control and Complications Trial (DCCT)/Epidemiology of Diabetes Interventions and Complications (EDIC) Study Research Group. Intensive diabetic treatment and cardiovascular outcomes in type 1 diabetes: The DCCT/EDIC study 30-year follow-up. Diabetes Care2016;39:686-693pmid:26861924.

[86] The DCCT Research Group. Reliability and validity of a diabetes quality-of-life measure for the Diabetes Control and Complications Trial (DCCT). Diabetes Care 1988;11:725-32.

[87] The Diabetes Control and Complications Trial/Epidemiology of Diabetes Inter- ventions and Complications (DCCT/EDIC) Study Research Group. Intensive diabetes treatment and cardiovascular disease in patients with type 1 diabetes. N Engl J Med 2005;353:264353.

[88] Strawbridge LM, Lloyd JT, Meadow A, Riley GF, Howell BL. Oneyear outcomes of diabetes self-management training among Medicare beneficiaries newly diagnosed with diabetes. Med Care2017;55:391397.

[89] Bergenstal RM, Gal RL, Connor CG, et al. Racial differences in the relationship of glucose concentrations and hemoglobin A1c levels. Ann Intern Med 2017;167:95-102

[90] Nathan DM, Kuenen J, Borg R, Zheng H, Schoenfeld D, Heine RJ. Translating the $\mathrm{A} 1 \mathrm{C}$ assay into estimated average glucose values. Diabetes Care 2008;31:1473-1478.

[91] Beck RW, Connor CG, Mullen DM, Wesley DM, Bergenstal RM. The fallacy of average: how using $\mathrm{HbAlc}$ alone to assess glycemic control can be misleading. Diabetes Care 2017;40:994-999.

[92] DeWalt DA, Davis TC, Wallace AS, et al. Goal setting in diabetes selfmanagement: taking the baby steps to success. Patient Educ Couns 2009; 77: 218-223pmid:19359123.

[93] Atualização sobre hemoglobina glicada (HbA1) para avaliação do controle glicêmico e para o diagnostico do diabetes: aspectos clínicos e laboratoriais Disponível em: http://www.scielo.br/pdf/jbpml/v45n1/07.pdf Acesso em julho de 2019.

[94] Knowler WC, Barrett-Connor E, Fowler SE, et al.; Diabetes Prevention Program Research Group. Reduction in the incidence of type 2 diabetes with lifestyle intervention or metformin. N Engl J Med2002;346:393 403.

[95] Wing RR, Edelstein SL, et al. Effect of weight loss with lifestyle intervention on risk of diabetes. Diabetes Care 2006;29:2102-2107?

[96] Ley SH, Hamdy O, Mohan V, Hu FB. Prevention and management of type 2 diabetes: dietary components and nutritional strategies. Lancet 2014:383:1999-2007.

[97] Jacobs S, Harmon BE, Boushey CJ, et al. A priori-defined diet quality indexes and risk of type 2 diabetes: the Multiethnic Cohort. Diabetologia 2015;58:98-112.

[98] Chiuve SE, Fung TT, Rimm EB, et al. Alternative dietary indices both strongly predict risk of chronic disease. J Nutr 2012;142:1009-1018.

[99] Schwingshackl L, Bogensberger B, Hoffmann G. Diet quality as assessed by the Healthy Eating Index, Alternate Healthy Eating Index, Dietary Approaches to Stop Hypertension score, and health outcomes: an updated systematic review and meta-analysis of cohort studies. J Acad Nutr Diet2018;118:74-100.e11. 
[100] Management of Postmeal Glucose - Innternacional Diabetes Federation Disponível em: https://www.idf.org/e-library/guidelines/82management-of-postmeal-glucose.html. Acesso em 15 de agosto de 2019.

[101]Posicionamento Oficial SBD n0 04/2019: O papel do sistema de infusa?o conti?nua de insulina, bomba de insulina, no tratamento do diabetes.

Disponível em:https://www.diabetes.org.br/profissionais/images/2019/posiciona mento2019/PAPEL-SISTEMA-INFUSAO.pdf Acesso em outubro 2019.

[102]Protocolo Clínico E Diretrizes Terapêuticas Para A Dispensação De Sensor De Glicose. Secretaria de saúde Governo do Estado do Espírito Santo. Disponível em: https://saude.es.gov.br/Media/sesa/Consulta\%20Pública/Protocolo\%2 OSensores\%20de\%20Glicose.pdf Acesso em:16 de Agosto de 2019.

[103]Diabetes: pesquisa avalia os fatores associados à qualidade de vida. Disponível em:https://portal.fiocruz.br/noticia/diabetes-pesquisaavalia-os-fatores-associados-qualidade-de-vida Acesso em agosto de 2019.

[104]Diabetes Trials Unit http://www.dtu.ox.ac.uk/ - Acesso em 13 de Agosto de 2019.

[105]Monnier L, Colette C, Wojtusciszyn A, et al. Toward defining the threshold between low and high glucose variability in diabetes. Diabetes Care 2017;40:832-838pmid:28039172.

[106] Monnier L, Colette C, Dejager S, Owens DR. Near normal HbA1c with stable glucose homeostasis: the ultimate target/aim of diabetes therapy. Rev Endocr Metab Disord2016;17:91-101pmid:26803295.

[107]Abbott. Freestyle Libre User Manual. 2016.

[108]Uso da tecnologia e das novas terapias para tomada de decisões terapêuticas no DM. https://www.diabetes.org.br/profissionais/albums/37-recife - Acesso em 13 de Agosto de 2019.

[109] Revista Portuguesa de Diabetes. 2018; 13 (4): 143-153 NATIONAL CONSENSUS - Consenso Nacional para a Utilizac?a?o do Sistema de Monitorizac?a?o Flash da Glicose National Consensus on the Use of the Glucose Flash Monitoring System disponível em http://www.revportdiabetes.com/wp-content/uploads/2019/01/RPDDEzembro-2018-Consenso-Nacional-págs-143-153.pdf Acesso em 22 de agosto de 2019.

[110]Six-Month Randomized, Multicenter Trial of Closed-Loop Control in Type 1 Diabetes. N Engl J Med. 2019 Oct 31;381(18):1707-1717. doi: 10.1056/NEJMoa1907863. Epub 2019 Oct 16.

[111]Determinação Das Glicemias Capilar E Venosa Com Glicosímetro Versus Dosagem Laboratorial Da Glicose Plasmática - Jorna Brasileiro de Patologia e Medicina Laboratorial. Disponível em: http://www.scielo.br/scielo.php?script=sci_arttext\&pid=S167624442009000500006 Acesso em: 12 de agosto de 2019.

[112]Brown SA, Kovatchev BP, Raghinaru D, et al. Six-month randomized, multicenter trial of closed-loop control in type 1 diabetes. $\mathrm{N}$ Engl J Med. 2019;381:1707-1717.

[113]Protocolo Clínico e Diretrizes Terape?uticas Diabetes Mellitus Tipo 1 Disponível em: http://conitec.gov.br/images/Relatorios/2018 /Relatorio.PCDTDM2018.pdf Acesso em 08 de agosto de 2019.

[114]American Diabetes Association. 6. Glycemic Targets: Standards of Medical Care in Diabetes-2018. Diabetes Care 2018; 41:S55.

[115]Harmonizing Hemoglobin A1C Testing. http://www.ngsp.org - Acesso em 14 de Agosto de 2019.

[116] Hypo and Hyperglycemia in Relation to the Mean, Standard Deviation, Coefficient of Variation, and Nature of the Glucose Distribution Disponível

https://www.liebertpub.com/doi/10.1089/dia.2012.0062 Acesso em Agosto de 2019.

[117]Chandalia, H.B. and Krishnaswamy, P.R. Glycated Hemoglobin lu2013 Current Science. (83)12:1522-1532, 2002. Disponível em: https://pdfs.semanticscholar.org/2ff1/75109034a4f12be326b8578d0dc $12040 f d 8$ e.pdf Acesso em 23 de agosto de 2019.

[118] Time in Range, as a Novel Metric of Glycemic Control, Is Reversely Associated with Presence of Diabetic Cardiovascular Autonomic Neuropathy Independent of HbA1c in Chinese Type 2 Diabetes. Volume 2020 |Article ID $5817074 \quad 11$ pages https://doi.org/10.1155/2020/5817074.

[119]T. Danne, R. Nimri, T. Battelino et al., "International consensus on use of continuous glucose monitoring," Diabetes Care, vol. 40, no. 12, pp. 1631-1640, 2017.

[120]J. Fleischer, "Diabetic autonomic imbalance and glycemic variability," Journal of Diabetes Science and Technology, vol. 6, no. 5, pp. 1207 1215, 2012.

[121]R. W. Beck, R. M. Bergenstal, T. D. Riddlesworth et al., "Validation of time in range as an outcome measure for diabetes clinical trials," Diabetes Care, vol. 42, no. 3, pp. 400-405, 2019.
[122] V. Spallone, F. Bellavere, L. Scionti et al., "Recommendations for the use of cardiovascular tests in diagnosing diabetic autonomic neuropathy," Nutrition, Metabolism, \& Cardiovascular Diseases, vol. 21, no.1, pp. 69-78, 2011.

[123]The DCCT Research Group, "The Diabetes Control and Complications Trial (DCCT). Design and methodologic considerations for the feasibility phase. The DCCT Research Group," Diabetes, vol. 35, no. 5, pp. 530-545, 1986.

[124]UK Prospective Diabetes Study (UKPDS) Group, "Intensive bloodglucose control with sulphonylureas or insulin compared with conventional treatment and risk of complications in patients with type 2 diabetes (UKPDS 33)," The Lancet, vol. 352, no. 9131, pp. 837 853,1998 .

[125]UKPDS risk engine. Oxford, United Kingdom: Oxford Centre for Diabetes, En- docrinology and Metabolism, 2017 (https:// www.dtu.ox.ac.uk/riskengine).

[126] American Diabetes Association, "Standards of medicalcare in diabetes2017: summary of revisions," Diabetes Care, vol. 39, Supplement 1,pp. S4-S5, 2017

[127]J. M. Lachin, S. Genuth, D. M. Nathan, B. Zinman, B. N. Rutledge, and DCCT/EDIC Research Group, "Effect of glycemic exposure on the risk of microvascular complications in the diabetes control and complications trial--revisited," Diabetes, vol. 57, no. 4, pp. 995-1001, 2008.

[128]S. T. Andersen, D. R. Witte, J. Fleischer et al., "Risk factors for the presence and progression of cardiovascular autonomic neuropathy in type 2 diabetes: ADDITION-Denmark," Diabetes Care, vol. 41, no. 12 , pp. 2586-2594, 2018.

[129]R. A. Vigersky and C. McMahon, "The relationship of hemoglobin A1C to time-in-range in patients with diabetes," Diabetes Technology \& Therapeutics, vol. 21, no. 2, pp. 81-85, 2019.

[130]L. A. Wright and I. B. Hirsch, "Metrics beyond hemoglobin A1C in diabetes management: time in range, hypoglycemia, and other parameters," Diabetes Technology \& Therapeutics, vol. 19, no. S2, pp.S16-S26, 2017.

[131]A.S. Omar, A. Salama, M. Allam et al., "Association of time in blood glucose range with outcomes following cardiac surgery," BMC Anesthesiology, vol. 15, article 14, 2015.

[132] J. Lu, X. Ma, J. Zhou et al., "Association of time in range, as assessed by continuous glucose monitoring, with diabetic retinopathy in type 2 diabetes," Diabetes Care, vol. 41, no. 11, pp. 2370-2376, 2018.

[133]J. E. Jun, S. E. Lee, Y. B. Lee et al., "Continuous glucose monitoring defined glucose variability is associated with cardiovascular autonomic neuropathy in type 1 diabetes," Diabetes/Metabolism Research and Reviews, vol. 35, no. 2, article e3092, 2019.

[134]D. Matsutani, M. Sakamoto, H. Iuchi et al., "Glycemic variability in continuous glucose monitoring is inversely associated with baroreflex sensitivity in type 2 diabetes: a preliminary report," Cardiovascular Diabetology, vol. 17, no. 1, p. 36, 2018.

[135]Diabetes Technology: Review of the 2019 American Diabetes Association Standards of Medical Care in Diabetes.

[136] Implantable Sensors. Disponível em: https://sbd.eadbox.com/courses/sitec-2019-simposio-internacional-detecnologias-em-diabetes Acesso em julho de 2019.

[137]Lind M, Polonsky W, Hirsch IB, et al. Continuous glucose monitoring vs conventional therapy for glycemic control in adults with type 1 diabetes treated with multiple daily insulin injections: the GOLD randomized clinical trial. JAMA. 2017;317:379-87. [PMID: 28118454] doi:10.1001/jama.2016.19976.

[138]U.S. Food and Drug Administration. FDA news release: FDA expands indication for continuous glucose monitoring system, first to replace fingerstick testing for diabetes treatment decisions. Disponível em: www.fda.gov/newsevents/newsroom/pressannouncements/ucm53405 6.htm Acesso em 14 Julho 2019.

[139]Performance of the Freestyle ${ }^{\circledR}$ Libre flash glucose monitoring (flash GM) system in people with type 1 diabetes: a secondary outcome analysis of a randomised crossover trial.

[140] Mullen DM, Bergenstal R, Criego A, Arnold KC, Goland R, Richter S. Time savings using a standardized glucose reporting system and ambulatory glucose profile. J Diabetes Sci Technol2018;12:614621pmid:29169243.

[141]Carlson AL, Mullen DM, Bergenstal RM. Clinical use of continuous glucose monitoring in adults with type 2 diabetes. Diabetes Technol Ther 2017;19(Suppl. 2):S4-S11pmid:28541137.

[142]Lawlor KB, Hornyak MJ. SMART goals: how the application of SMART goals can contribute to achievement of student learning outcomes. Developments in Business Simulation and Experiential Learning: Proceedings of the Annual ABSEL Conference 2012;39:259-267. 
[143]DiMeglio LA, Acerini C, Codner E, et al. ISPAD Clinical Practice Consensus Guidelines 2018: glycemic control targets and glucose monitoring for children, adolescents, and young adults with diabetes. Pediatr Diabetes 2018;19:105-114.

[144]W. Xu, Y. Zhu, X. Yang et al., "Glycemic variability is an important risk factor for cardiovascular autonomic neuropathy in newly diagnosed type 2 diabetic patients," International Journal of Cardiology, vol. 215, pp. 263-268, 2016.

[145]Glycemic Targets: Standards of Medical Care in Diabetes-2020. American Diabetes Association Diabetes Care 2020 Jan; 43(Supplement 1): S66-S76. https://doi.org/10.2337/dc20-S006.

[146]Beck RW, Bergenstal RM, Cheng P, et al. The relationships between time in range, hyperglycemia metrics, and $\mathrm{HbA1c}$. J Diabetes $\mathrm{Sci}$ Technol 2019;13:614-626.

[147]Comparação Entre Determinaçõeses De Glicemia Capilar E Venosa Com Glicosímetros E Dosagem Laboratorial Da Glicose Plasmática Venosa - Revista Médica de Minas Gerais. Disponível em: http://rmmg.org/artigo/detalhes/2054 Acesso em: 18 de agosto de 2019.

[148]Beck, RW, et al. Diabetes Care 2019; 42:400-5.

[149]Battelino T, Danne T, Bergenstal RM, et al. Clinical targets for continuous glucose monitoring data interpretation: recommendations from the international consensus on time in range. Diabetes Care2019;42:1593-1603.

[150]SBD chancela o Consenso de Tempo no Alvo (Time in range, TIR) Disponível em: https://www.diabetes.org.br/publico/palavra-dapresidente/1950-sbd-chancela-o-consenso-de-tempo-no-alvo-time-inrange-tir Acesso em 20 de agosto de 2019.

[151]Posicionamento Oficial SBD n0 03/2019: Utilização de setas de tendência para pacientes com diabetes mellitus em monitorização contínua de glicose. Disponível em: https://www.diabetes.org.br/profissionais/images/SETAS.pdf Acesso em outubro 2019.

[152] Consenso Brasileiro de uso das setas de tendëncia | Melanie Rodacky Disponível em: https://sbd.eadbox.com/courses/sitec-2019-simposiointernacional-de-tecnologias-em-diabetes Acesso em julho de 2019.

[153] http://tmedweb.tulane.edu/pharmwiki/doku.php/rx_of_diabetes.

[154]http://solmedicamentosespeciais.com.br/endocrinologia/insulinainalavel-afrezza/.

[155]http://www.medtronicdiabetes.com/products/i-port-advance.

[156]DeFronzo, Diabetes. 2009;58 773-795.

[157]https://diatribe.org/BeyondA1c.

[158]https://www.touchendocrinology.com/advances-in-type-1-diabetestechnology-over-the-last-decade/.

[159] dexcom.com access aug/2019.

[160]https://www.diabetesdaily.com/.

[161] Oficial SBD n0 03/2019.

[162]http://www.a1cbloodtest.net/a1c-complications.php.

[163]ADA Clinical Targets for Continuous Glucose Monitoring Data Interpretation: Recommendations from the International Consensus on Time in Range. 